\title{
Yield and Yield Attributes of Hybrid Mustard as Affected by Crop Geometry and Varieties
}

\author{
Anindita Das, Manabendra Ray and Kanu Murmu* \\ Department of Agronomy, Faculty of Agriculture, Mohanpur, Nadia, India \\ *Corresponding author
}

\begin{tabular}{|l|}
\hline Ke y w or d s \\
Mustard, Genotype, \\
Crop geometry, \\
Yield \\
\hline Article Info \\
\hline Accepted: \\
17 March 2019 \\
Available Online: \\
10 April 2019 \\
\hline \hline
\end{tabular}

A B S T R A C T

A field experiment was carried out in the CR Farm of Gayeshpur, BCKV, Nadia, West Bengal, India during rabi season of 2015-16 and 2016-17 to find out suitable hybrid variety and optimum spacing for different hybrids. Three hybrid varieties of mustard viz. Kesari 5111( $\left(\mathrm{V}_{1}\right)$, Kesari 5222( $\left(\mathrm{V}_{2}\right)$ and Kesari Gold $\left(\mathrm{V}_{3}\right)$ were taken as treatments in the main plot, whereas, four spacing - 30cm $\times 10 \mathrm{~cm}\left(\mathrm{~S}_{1}\right), 30 \mathrm{~cm} \times 20 \mathrm{~cm}\left(\mathrm{~S}_{2}\right), 40 \mathrm{~cm} \times 20 \mathrm{~cm}$ $\left(\mathrm{S}_{3}\right)$ and $40 \mathrm{~cm} \times 30 \mathrm{~cm}\left(\mathrm{~S}_{4}\right)$ were imposed as subplot treatment. The experiment was conducted in split plot design with 3 replications and repeated in rabi seasons for two consecutive years (2015-16 and 2016-17). The results of the experiment revealed that the maximum seed yield was recorded in Kesari Gold (1746 and $2153 \mathrm{~kg} \mathrm{ha}^{-1}$ respectively in $1^{\text {st }}$ and $2^{\text {nd }}$ year) followed by Kesari 5111. Regarding plant geometry significantly higher yield was noticed in $30 \mathrm{~cm} \times 20 \mathrm{~cm}\left(1689 \mathrm{kgha}^{-1}\right.$ and $2244 \mathrm{~kg} \mathrm{ha}^{-1}$ respectively in $1^{\text {st }}$ and $2^{\text {nd }}$ year). Crop geometry $40 \mathrm{~cm} \times 30 \mathrm{~cm}$ observed superior with respect of number of primary branches/plant and seeds/siliqua, but it was not reflected on seed yield due to less number of plants per unit area. The hybrid varieties of mustard are highly suitable in Gangetic plains of West Bengal due to their higher yields. Slightly wider spacing $(30 \mathrm{~cm} \times$ $20 \mathrm{~cm}$ ) is suitable for hybrids because of their bigger canopy.

\section{Introduction}

Indian mustard (Brassica juncea L.) belonging to family Cruciferae is one of the most important winter oilseed crops, occupies a prominent place among oilseed crop being next to groundnut in importance. Presently rapeseed mustard sown area in India is 6.36 mha, with a production of $8.03 \mathrm{mt}$. The average productivity is $1262 \mathrm{kgha}^{-1}$ (Directorate of Economics and Statistics, Department of Agriculture and Cooperation, 2012-13), which needs to be enhanced upto
$2562 \mathrm{kgha}^{-1}$ by 2030 for ensuring edible oil for self-reliance (DRMR, 2011). Indian mustard is a fairly high remunerative crop with a major source of high quality edible oil and for increasing the productivity of mustard crop the improved varieties which are capable of giving high yields like hybrid varieties need to be cultivated. Selection of varieties depends mainly on the several factors eg. method of sowing, crop rotation, pest and disease management, irrigation facilities, climatic conditions etc. Planting geometry i.e row spacing is one of the very important 
practices for mustard production (Mondal et al., 1999). Suboptimal planting geometry, wider rows and plant spacing lead to low population which in turn fail to compensate the yield obtained in optimum plant stand while narrower row and plant spacing increase the inter and intra-plant competition leading to poor growth and development and dry matter accumulation resulting in poor yield. Improved varieties of mustard or hybrid are capable of higher yields when grown under optimum row spacing and fertility level. Decreasing crop yield in improper spacing has been reported by many workers (McDonald et al., 1983). The improper row spacing of mustard decreased seed yield through synchronization of silique filling period with high temperature, the decreased in assimilates production, drought stress occurrence, shortened silique filling period and acceleration of plant maturity (Mendham et al., 1995). Hence an attempt was made to study the effect of varieties and sowing method on yield attributes and yield of hybrid mustard under Gangetic alluvial soil of West Bengal.

\section{Materials and Methods}

A field experiment was conducted at Regional Research station, New Alluvial Zone, Bidhan Chandra KrishiViswavidyalaya, Gayeshpur, Nadia. The experimental site is situated at $23^{\circ} 8^{\prime} \mathrm{N}$ latitude and $88^{\circ} \mathrm{E}$ longitudes having an average altitude of $9.75 \mathrm{~m}$ above mean sea level. The soil of the experimental site was Gangetic alluvial with sandy clay loam texture, good water holding capacity, well drained and moderate fertility status. The experimental site located in sub-humid, subtropical zone and lies in Indo-Gangetic alluvial agro-ecological zone. The average annual rainfall ranged from 1300 to $1450 \mathrm{~mm}$ and major portion of rainfall is generally received during the month of June to middle of October. The mean monthly temperature ranged from $9^{\circ} \mathrm{C}$ to $36^{\circ} \mathrm{C}$. During the crop growing period maximum temperature varied from $31.9^{\circ} \mathrm{C}$ to $31.3^{\circ} \mathrm{C}(2015-16), 29.7^{\circ} \mathrm{C}$ to $28^{\circ} \mathrm{C}$ (2016-17) and minimum temperature varied between $21.8^{\circ} \mathrm{C}$ to $18.8^{\circ} \mathrm{C}(2015-16)$, 20.5 to $17.7^{\circ} \mathrm{C}$ (2016-17). The mean maximum relative humidity was highest in the month of November $(93.3 \%$ in 2015 and $93.4 \%$ in 2016), whereas the mean minimum relative humidity was in March $(47.5 \%$ in 2016 and $45.6 \%$ in 2017). Three mustard hybrid variety namely V1- Kesari 5111, V2Kesari 5222, V3- Kesari Gold as main plot treatment and $\mathrm{S} 1-30 \mathrm{~cm} \times 10 \mathrm{~cm}, \mathrm{~S} 2-30 \mathrm{~cm}$ x $20 \mathrm{~cm}, \mathrm{~S} 3-40 \mathrm{~cm}$ x $20 \mathrm{~cm}, \mathrm{~S} 4-40 \mathrm{~cm}$ x 30 $\mathrm{cm}$ as sub-plot treatment were included in the experiment. Land was prepared by 4 ploughing followed by planking after each ploughing. The land was made free from weeds and stubble of previous crop. After proper levelling the whole experimental field was divided into 3 equal blocks. Then each of the blocks were divided into 3 main-plots and ultimately each of the main-plot were again split into 4 equal sub-plots. Mustard crop was sown in line with the help of tyne as per treatment. The crop was fertilized with a uniform amount of nitrogene, phosphorus and potassium at the rate of 80,40 and $40 \mathrm{~kg} / \mathrm{ha}$ respectively. The $50 \%$ dose of $\mathrm{N}$ and full dose of $\mathrm{P}_{2} \mathrm{O}_{5}$ and $\mathrm{K}_{2} \mathrm{O}$ were applied as basal. The rest amount of nitrogen was applied in two splits with the equal amount at 21 DAS and at 42 DAS. Five plants were randomly selected from each plot and tagged. The total no. of primary branches produced per plant counted at harvest from five tagged plants in all treatments. The mean of five plants were represented as the no. of primary branch per plant. Total no. of siliqua per plant was recorded from five tagged plants. Mean of five plants was recorded as the no. of siliqua produced per plant. Randomly 5 siliqua were chosen from siliqua of 5 tagged plants and seeds were counted in each siliqua and their mean was recorded as number of 
seeds/siliqua. The weight of thousand grains (g) was recorded from the grain samples drawn from the produce obtained from each of net plot. Yield was determined from the well dried seeds collected from net plot area excluding the border effect each plot. Then the mean yield was converted into $\mathrm{kg} / \mathrm{ha}$. Biological yield from net plot was calculated and expressed as $\mathrm{kg} / \mathrm{ha}$. Stover yield of each net plot was recorded after complete sun drying and expressed in $\mathrm{kg} / \mathrm{ha}$. Biological yield from net plot was calculated and expressed as $\mathrm{kg} / \mathrm{ha}$. Biological yield was obtained by summing seed yield and stover yield from net plot.

\section{Results and Discussion}

The no. of primary branches per plant, no. of siliqua/plant, no. of seeds/siliqua and test weight are important yield attributing character for Indian mustard. Effect of varieties and crop geometry on yield component has been presented in Table 1. No. of primary branches were significantly influenced by varieties in 1st year and maximum no. were recorded by Kesari Gold (7). Crop geometry significantly influenced the no. of primary branches. Maximum no. of primary branches (7.78) was obtained at 40 $\mathrm{cm} \times 30 \mathrm{~cm}$ spacing during 1st year and in 2nd year S3 recorded higher no. of primary branches (6.31) which is at par with S4. Number of siliqua/ plant and no. of seeds/siliqua were significantly influenced by varieties. Kesari Gold recorded maximum no. (367.93 and 306.90 respectively in 1 st and 2nd year) and S4 spacing i.e. $40 \mathrm{~cm} \times 30 \mathrm{~cm}$ recorded maximum no. of siliqua/plant. Singh et al., (2001) conducted an experiment in Jodhpur and observed that number of siliqua/plant recorded higher in cultivar Pusa Bold (257) compared to cultivar TS9 (198). In interaction (Table 2) maximum number of siliqua /plant was recorded by V3 (Kesari Gold) along with spacing S3 spacing
(496.00). Wider spacing favours higher number of siliqua/plant. Difference of siliqua number among different varieties may be due to genetic character. Somondal et al., (2012) recorded different number of siliqua/plant by different mustard varieties.

Maximum no. of seeds/siliqua were obtained in Kesari 5111 (14.58) in $1^{\text {st }}$ year and Kesari Gold (16.46) in $2^{\text {nd }}$ year. Crop geometry significantly influences the no. of seeds/siliqua in $2^{\text {nd }}$ year. Maximum no. was found at $40 \mathrm{~cm} \times 30 \mathrm{~cm}$ spacing. It has been observed that varieties significantly influence the test weight. Highest test weight was found in Kesari Gold (6.78) in $1^{\text {st }}$ year and in $2^{\text {nd }}$ year Kesari 5111 (5.36) recorded highest test weight, which is at par with V3 i.e. Kesari Gold. Crop geometry did not show any significant effect on test weight. Yield contributing characters were highest in V3Kesar Gold and lowest in V2 - Kesari 5222. Although interaction effect did not show any significant effect on yield attributing characters except for no. of siliqua/ plant in the first year. The findings are in line with Mamun (2005) who stated that yield contributing characters are higher in HYV of mustard.

Seed yield (kg/ha) as affected by varieties and crop geometry have been presented in (Table 3). A perusal of data showed that different crop geometry influenced significantly to the seed yield. Among the varieties highest seed yield $\left(1746 \mathrm{~kg} / \mathrm{ha}\right.$ and $2153 \mathrm{~kg} / \mathrm{ha}$ respectively $1^{\text {st }}$ and $2^{\text {nd }}$ year) was recorded by Kesari Gold which was significantly higher than Kesari 5111 (V1) and Kesari 5222(V2). The minimum seed yield $\left(1358 \mathrm{~kg} / \mathrm{ha}\right.$ and $1623 \mathrm{~kg} / \mathrm{ha}$ respectively $1^{\text {st }}$ and $2^{\text {nd }}$ year) was recorded in $\mathrm{V} 2$ variety i.e Kesari 5222. Maximum seed yield (1689 kg/ha and $2244 \mathrm{~kg} /$ ha respectively in $1^{\text {st }}$ and $2^{\text {nd }}$ year) was recorded when the crop was shown on 30 $\mathrm{cm} \times 20 \mathrm{~cm}$, which was superior over other spacing. 
Table.1 Effect of varieties and spacing on yield component of hybrid mustard

\begin{tabular}{|c|c|c|c|c|c|c|c|c|}
\hline \multirow[t]{2}{*}{ Treatments } & \multicolumn{2}{|c|}{$\begin{array}{l}\text { No. of primary } \\
\text { branches/plant }\end{array}$} & \multicolumn{2}{|c|}{$\begin{array}{c}\text { No. of } \\
\text { siliqua/plant }\end{array}$} & \multicolumn{2}{|c|}{$\begin{array}{c}\text { No. of } \\
\text { seeds/siliqua }\end{array}$} & \multicolumn{2}{|c|}{ Test weight(g) } \\
\hline & 2015-16 & 2016-17 & 2015-16 & 2016-17 & 2015-16 & 2016-17 & 2015-16 & 2016-17 \\
\hline V1 & 6.58 & 6.32 & 289.47 & 256.43 & 14.58 & 14.87 & 4.30 & 5.36 \\
\hline V2 & 6.08 & 5.47 & 295.83 & 186.95 & 13.67 & 13.25 & 6.34 & 5.07 \\
\hline V3 & 7.00 & 5.97 & 367.93 & 306.90 & 12.08 & 16.46 & 6.78 & 5.25 \\
\hline $\operatorname{S.Em}( \pm)$ & 0.17 & 0.24 & 17.91 & 20.80 & 0.25 & 0.25 & 0.01 & 0.05 \\
\hline CD at $5 \%$ & 0.68 & NS & 70.31 & 81.64 & 1.00 & 1.00 & 0.05 & 0.18 \\
\hline S1 & 5.22 & 5.22 & 180.87 & 146.06 & 12.67 & 13.64 & 5.77 & 5.17 \\
\hline $\mathbf{S 2}$ & 6.56 & 5.89 & 335.44 & 266.28 & 13.33 & 14.69 & 5.77 & 5.21 \\
\hline S3 & 6.67 & 6.31 & 329.00 & 280.89 & 13.89 & 16.09 & 5.81 & 5.27 \\
\hline S4 & 7.78 & 6.24 & 425.67 & 307.14 & 13.89 & 15.01 & 5.87 & 5.27 \\
\hline $\operatorname{S.Em}( \pm)$ & 0.26 & 0.21 & 25.94 & 14.91 & 0.47 & 0.41 & 0.01 & 0.02 \\
\hline CD & 0.77 & 0.62 & 77.07 & 44.28 & NS & 1.23 & NS & NS \\
\hline
\end{tabular}

Table.2 Interaction effect of varieties and spacing on yield component of hybrid mustard

\begin{tabular}{|c|c|c|c|c|c|c|c|c|}
\hline \multirow[t]{2}{*}{ Treatments } & \multicolumn{2}{|c|}{$\begin{array}{l}\text { No. of primary } \\
\text { branches/plant }\end{array}$} & \multicolumn{2}{|c|}{ No. of siliqua/plant } & \multicolumn{2}{|c|}{ No. of seeds/siliqua } & \multicolumn{2}{|c|}{ Test weight } \\
\hline & 2015-16 & 2016-17 & 2015-16 & 2016-17 & 2015-16 & 2016-17 & 2015-16 & 2016-17 \\
\hline V1S1 & 5.67 & 5.67 & 153.20 & 153.20 & 15.00 & 15.00 & 4.27 & 5.30 \\
\hline V1S2 & 6.67 & 6.53 & 325.67 & 235.73 & 14.33 & 14.27 & 4.27 & 5.31 \\
\hline V1S3 & 6.00 & 6.60 & 238.33 & 316.07 & 14.67 & 15.53 & 4.31 & 5.40 \\
\hline V1S4 & 8.00 & 6.47 & 440.67 & 320.73 & 14.33 & 14.67 & 4.34 & 5.45 \\
\hline V2S1 & 4.33 & 4.33 & 221.00 & 89.07 & 11.33 & 11.33 & 6.29 & 5.00 \\
\hline V2S2 & 6.00 & 5.67 & 330.00 & 222.87 & 14.00 & 13.40 & 6.30 & 5.05 \\
\hline V2S3 & 6.67 & 6.20 & 252.67 & 216.93 & 14.67 & 15.33 & 6.33 & 5.17 \\
\hline V2S4 & 7.33 & 5.67 & 379.67 & 218.93 & 14.67 & 12.93 & 6.44 & 5.07 \\
\hline V3S1 & 5.67 & 5.67 & 168.40 & 195.92 & 11.67 & 14.58 & 6.74 & 5.21 \\
\hline V3S2 & 7.00 & 5.47 & 350.67 & 340.25 & 11.67 & 16.42 & 6.75 & 5.27 \\
\hline V3S3 & 7.33 & 6.13 & 496.00 & 309.67 & 12.33 & 17.42 & 6.80 & 5.24 \\
\hline V3S4 & 8.00 & 6.60 & 456.67 & 381.75 & 12.67 & 17.42 & 6.83 & 5.30 \\
\hline $\operatorname{SEm}( \pm)$ & 0.45 & 0.36 & 44.94 & 25.82 & 0.82 & 0.71 & 0.02 & 0.04 \\
\hline CD at $5 \%$ & NS & NS & 133.50 & NS & NS & NS & NS & NS \\
\hline
\end{tabular}


Table.3 Effects of varieties and spacing on seed yield, stover yield and harvest index of hybrid mustard

\begin{tabular}{|c|c|c|c|c|c|c|}
\hline \multirow{2}{*}{ Treatments } & \multicolumn{2}{|c|}{ Seed yield(kg/ha) } & \multicolumn{2}{|c|}{ Stover yield(kg/ha) } & \multicolumn{2}{c|}{ Harvest index (\%) } \\
\cline { 2 - 7 } & $\mathbf{2 0 1 5 - 1 6}$ & $\mathbf{2 0 1 6 - 1 7}$ & $\mathbf{2 0 1 5 - 1 6}$ & $\mathbf{2 0 1 6 - 1 7}$ & $\mathbf{2 0 1 5 - 1 6}$ & $\mathbf{2 0 1 6 - 1 7}$ \\
\hline V1 & 1532 & 1816 & 4361 & 3372 & 25.97 & 29.61 \\
\hline V2 & 1358 & 1623 & 6301 & 4842 & 19.83 & 22.45 \\
\hline V3 & 1746 & 2153 & 6417 & 4769 & 18.20 & 26.11 \\
\hline S.Em $( \pm)$ & $\mathbf{5 5 . 4 7}$ & $\mathbf{9 8 . 0 4}$ & $\mathbf{2 7 5}$ & $\mathbf{2 5 9 . 4 2}$ & $\mathbf{0 . 5 3}$ & $\mathbf{2 . 3 1}$ \\
\hline CD at 5\% & $\mathbf{2 1 7 . 7 3}$ & $\mathbf{3 8 4 . 8 4}$ & $\mathbf{1 0 8 1}$ & $\mathbf{1 0 1 8 . 3 0}$ & $\mathbf{2 . 0 7}$ & $\mathbf{9 . 0 6}$ \\
\hline S1 & 1349 & 1705 & 5822 & 4383 & 19.16 & 27.88 \\
\hline S2 & 1689 & 2244 & 5989 & 5148 & 22.07 & 23.35 \\
\hline S3 & 1641 & 1886 & 6029 & 4183 & 21.74 & 27.24 \\
\hline S4 & 1502 & 1620 & 4931 & 3598 & 22.36 & 25.76 \\
\hline S.Em( \pm ) & $\mathbf{6 8 . 2 8}$ & $\mathbf{9 6 . 9 9}$ & $\mathbf{2 3 9}$ & $\mathbf{2 5 2 . 5}$ & $\mathbf{0 . 5 6}$ & $\mathbf{1 . 6 0}$ \\
\hline CD at 5\% & $\mathbf{2 0 2 . 8 4}$ & $\mathbf{2 8 8 . 1 5}$ & $\mathbf{7 1 1}$ & $\mathbf{7 5 0 . 2}$ & $\mathbf{1 . 6 5}$ & $\mathbf{4 . 7 6}$ \\
\hline
\end{tabular}

Table.4 Interaction Effects of varieties and spacing on seed yield, harvest index, and productivity of rapeseed and mustard

\begin{tabular}{|c|c|c|c|c|c|c|}
\hline \multirow{2}{*}{ Treatments } & \multicolumn{2}{|c|}{ Seed yield(kg/ha) } & \multicolumn{2}{c|}{ Stover yield(kg/ha) } & \multicolumn{2}{c|}{ Harvest Index (\%) } \\
\cline { 2 - 7 } & $\mathbf{2 0 1 5 - 1 6}$ & $\mathbf{2 0 1 6 - 1 7}$ & $\mathbf{2 0 1 5 - 1 6}$ & $\mathbf{2 0 1 6 - 1 7}$ & $\mathbf{2 0 1 5 - 1 6}$ & $\mathbf{2 0 1 6 -}$ \\
& & & & & & $\mathbf{1 7}$ \\
\hline V1S1 & 1456 & 1763 & 4370 & 4050 & 25.00 & 25.00 \\
\hline V1S2 & 1758 & 2075 & 5000 & 4287 & 25.97 & 26.65 \\
\hline V1S3 & 1534 & 1856 & 4337 & 2732 & 25.84 & 36.11 \\
\hline V1S4 & 1380 & 1570 & 3736 & 2418 & 27.06 & 30.70 \\
\hline V2S1 & 1133 & 1604 & 6770 & 5966 & 16.38 & 21.32 \\
\hline V2S2 & 1401 & 1825 & 6117 & 5041 & 21.33 & 23.12 \\
\hline V2S3 & 1481 & 1560 & 6742 & 4677 & 20.81 & 22.82 \\
\hline V2S4 & 1416 & 1505 & 5574 & 3686 & 20.79 & 22.54 \\
\hline V3S1 & 1457 & 1748 & 6326 & 3133 & 16.09 & 37.33 \\
\hline V3S2 & 1907 & 2834 & 6849 & 6115 & 18.93 & 20.29 \\
\hline V3S3 & 1909 & 2243 & 7007 & 5140 & 18.57 & 22.78 \\
\hline V3S4 & 1711 & 1786 & 5485 & 4689 & 19.23 & 24.04 \\
\hline S.Em( $)$ & $\mathbf{1 1 8 . 2 6}$ & $\mathbf{1 6 8 . 0 0}$ & $\mathbf{4 1 4 . 7 6}$ & $\mathbf{4 3 7 . 4 3}$ & $\mathbf{0 . 9 6}$ & $\mathbf{2 . 7 7}$ \\
\hline CD at 5\% & NS & NS & NS & $\mathbf{1 2 9 9 . 5 2}$ & $\mathbf{N S}$ & $\mathbf{3 . 9 2}$ \\
\hline
\end{tabular}

The minimum seed yield (1503 kg/ha) was obtained when sowing was done at $30 \mathrm{~cm} \mathrm{x}$ $10 \mathrm{~cm}$. The seed yield was significantly affected by different varieties. As discussed earlier, the different hybrids have different yield potential, which is the reason for yield variation among different varieties. In contrast to the traditional OP varieties hybrids have bigger canopy structure and to explore optimum yield potential this hybrids needs wider spacing in comparison to OP varieties.. Rana and Pachauri (2001) observed that the 
seed yield recorded higher with $30 \mathrm{~cm} \times 10$ $\mathrm{cm}$ spacing $(1670 \mathrm{~kg} / \mathrm{ha})$ as compared to 45 $\mathrm{cm} \times 15 \mathrm{~cm}$ spacing $(1280 \mathrm{~kg} / \mathrm{ha})$.

Stover yield ( $\mathrm{kg} / \mathrm{ha})$ as affected by varieties and crop geometry have been presented in (Table 3). The stover yield (kg/ha) was significantly affected by different varieties. Highest stover yield (6417 kg/ha) was recorded by Kesari Gold in 1 st year and in $2^{\text {nd }}$ year it was recorded by Kesari 5222 (4842 $\mathrm{kg} / \mathrm{ha}$ ), which was at par with Kesari Gold. A perusal of data showed that different crop geometry influenced significantly to the stover yield. Maximum stover yield of (6029 $\mathrm{kg} / \mathrm{ha}$ ) was recorded when the crop was shown on $40 \mathrm{~cm} \times 20 \mathrm{~cm}$ during $1^{\text {st }}$ year and in $2^{\text {nd }}$ year highest stover yield $(5148 \mathrm{~kg} / \mathrm{ha})$ was recorded at $30 \mathrm{~cm} \times 20 \mathrm{~cm}$. In interaction table (Table 4) highest stover yield (6115 $\mathrm{g} / \mathrm{ha}$ ) was found when Kesari Gold was sown at $30 \mathrm{~cm}$ x $20 \mathrm{~cm}$ spacing. Mirza Hasanuzzaman and Md. Fazlul Karim (2007) conducted a field experiment in Bangladesh and reported that $30 \mathrm{~cm}$ row spacing produced highest stover yield (2933kg/ha).

Harvest index (\%) as affected by varieties and crop geometry have been presented in (Table 3). Maximum harvest index (25.97 \% and $29.61 \%$ respectively $1^{\text {st }}$ and $2^{\text {nd }}$ year) was recorded by Kesari 5111. Among the 3 hybrids Kesari 5111 recorded relatively less stover yield in comparison to its seed yield and ultimately showed higher harvest index. A perusal of data showed that different crop geometry influenced significantly to the yield. Maximum harvest index $(22.36 \%)$ was recorded when the crop was shown on $40 \mathrm{~cm}$ $\mathrm{x} 30 \mathrm{~cm}$ in $1^{\text {st }}$ year, whereas during $2^{\text {nd }}$ year $30 \mathrm{~cm} \times 10 \mathrm{~cm}$ attained $(27.88 \%)$ higher value. The harvest index (\%) was significantly affected by different varieties. In interaction table (Table 4) highest harvest index was found when Kesari Gold was sown at $30 \mathrm{~cm}$ x $10 \mathrm{~cm}$ spacing. Mirza
Hasanuzzaman and Md. FazlulKarim (2007) conducted a field experiment and reported that $30 \mathrm{~cm}$ row spacing produced highest harvest index $(36.20 \%)$.

Form the above results, it may be concluded that the variety Kesari Gold performed better followed by Kesari 5111 and then Kesari 5222. Seed yield and yield attributing characters of hybrid mustard was significantly affected by planting geometry. Wider spacing $(30 \mathrm{~cm} \times 20 \mathrm{~cm} / 40 \mathrm{~cm} \times 20 \mathrm{~cm})$ is essential for hybrid mustard cultivation. This management approach would be easy for farmers to implement because it would mean replacing their old varieties with new hybrid ones.

\section{References}

Directorate of Economics and Statistics, Department of Agriculture and Cooperation, 2012-13.

DRMR, 2011. Vision 2030. Directorate of Rapeseed-Mustard Research, Bharatpur, 321-303 Rajasthan, Pp30.

Hasanuzzaman, M. and Karim, M. F. 2007. Performance of Rapeseed (Brassica campestris L.) CV. SAU Sarisha-1 under different row spacing and irrigation level. Research Journal of Agriculture and Biological Sciences, 3(6): 960-965.

Mamun, F. A. 2005. Effect of different sources of nitrogenous fertilizers on the growth and yield of mustard mutant varieties. MS Thesis, Dept. of Agron., Bangladesh Agril. Univ., Mymensingh. pp. 55-58.

McDonald, G.K., Sutton, B.G. and Ellison F.W. 1983. The effect of time of sowing on the seed yield of mustard in the Namoi valley, New South Wales. Australian journal experimental agriculture and animal husbandry, 34: 229-240.

Mendham, N.J. and Salisbury, P.A. 1995. 
Physiology: Crop development, growth and yield in Brassica Oilseeds; Production and Utilization. (Ed. Kimber, D. and McGregor, D.I.). CAB International. Pp. 11-64.

Mondal RI, Biswas M, Hydar-Ali MK and Akbar MA 1999: Response of rapeseed genotype Dhali to seed rate and seeding date. Bangladesh J. Agril. Res., 24(1): 83-90.

Mondal RI, Biswas M, Hydar-Ali MK and Akbar MA 1999: Response of rapeseed genotype Dhali to seed

Mondal, R.I., Biswas, M., Hydar-Ali, M.K. and Akbar, M.A. 1999: Response of rapeseed genotype Dhali to seed rate and seedling date. Bangladesh Journal of Agricultural Research, 24(1): 83-
90.

Rana, D. S. and Pachauri, D.K. 2001. Sensitivity of zero erucic acid genotypes of Oleiferous brassica to plant population and planting geometry. Indian Journal of Agronomy, 46(4): 736-740.

rate and seeding date. Bangladesh J. Agril. Res., 24(1): 83-90.

Singh, R., Patidar, M and Singh, B. 2001. Response of Indian mustard cultivars to different sowing time. Indian Journal of Agronomy, 46(2): 292-295

Somondal, P. (2012). Varietal evaluation of rapeseed and mustard in new alluvial zone of West Bengal. M. Sc. Thesis, B.C.K.V, Mohanpur, Nadia, p-40.

\section{How to cite this article:}

Anindita Das, ManabendraRay and Kanu Murmu. 2019. Yield and Yield Attributes of Hybrid Mustard as Affected by Crop Geometry and Varieties. Int.J.Curr.Microbiol.App.Sci. 8(04): 2160-2166. doi: https://doi.org/10.20546/ijcmas.2019.804.253 